\title{
Asymmetric Information and Dividend Policy in Emerging Markets: Empirical Evidence from Nigeria
}

\author{
Godwin Chigozie Okpara \\ Department of Banking and Finance, Abia State University Uturu - Nigeria \\ Tel: 23-480-3817-5920_E-mail godgozie@yahoo.com
}

\begin{abstract}
The study investigated the relationship between asymmetric information and dividend policy in Nigeria. To carryout the research work, the researcher employed the unit root test using the augmented Dickey Fuller test, the Johanson cointegration test and then vector error correction model to ascertain the long-run relationship between the variables. Granger causality test was also used. The researcher found supportive evidence for the dividend signaling theory. Thus, there is a positive and significant relationship between dividend policy and asymmetric information. The Granger causality tests at lag 2 suggested that dividend policy has causal impact on information asymmetry without a reverse or feedback effect. That is dividend policy drives or granger causes information asymmetry.
\end{abstract}

Keywords: Asymmetric Information, Dividend Policy, Cointegration Test, Signaling Theory, Investors

\section{Introduction}

Market security information can be classified as information on the economy, market information, industry information and company information. Information about the economy therefore, is a necessary and important component of the investor's knowledge. Most investors and brokers interpret what is happening in the market by looking at the market indices. Hence, the importance of market information. Information concerning the entire industry is necessary for the understanding of the general trend of events in that industry. The state of the industry forms a base for performance evaluation of individual firms. Information about the management, raw material source, products and products' share of the market, past performance record of the firms etc; will enable the investor to form opinion of the firm and hence determine the value of the firm (Nwezeaku and Okpara, 2010).

Bick (1987), proposed that the price process relates to an exogenous "information process". Essentially the same approach is also used by Franke, Stapleton, and Subrahmanyam (1999) and Luders and Peisl (2001) who defined information process for the price of a non-dividend-paying asset as the conditional expectation process of the asset's final value. All individuals are assumed to monitor this information process and continuously revise their assessment of the asset's expected final value, which, by definition, equals the current value of the information process. All information is not easily and timely available and it involves cost. Certain kind of information provides signals to the market participants. According to Pandy (2008:420), though information is published publicly, sometimes, certain persons may have superior information than others. He described information asymmetry as the gap between information available with managers and what it actually shared with shareholders. Khang and King (2002) asserted that there is a widely accepted notion that corporate insiders often possess and trade on information about the value of their firm's shares (relative to the current stock price) that outside investors do not possess.

Brown and Hillegieist (2003) contended that information asymmetry in the stock market occurs when some investors possess additional information about the firm while others have only the publicly known ones. In the light of this, market players tend to perceive the same product differently and then offer different prices. Hasbrouck (1991) characterizing private information as "essentially prior knowledge of public information" indicates that timing differences account for much of the distinction between private and public information. Information asymmetry in the stock market occurs when one or more investors posses private information about the firm's value while other investors are uninformed. This information asymmetry gives insiders the ability to identify and take advantage of mispricing in the shares of their own firms. Jaffe (1974), Finnerty (1976), Seyhun (1986), Jeng, Metrick, and Zeckhauser (1999), and Lakonishok and Lee (2001) provided evidence that insiders earn significant abnormal profits from trading in their own firms' shares, though estimates of the size of these profits vary widely.

According to Valipor et al (2009) this dichotomy of information among investors is consistent with Admati and Pfleiderer (1988), Diamond and Verrecchia (1991), Easley and O'Hara (1992), Glosten and Milgrom (1985), Kim and Verrecchia (2001), Kyle (1985), and McNichols and Trueman (1994), among others. The level of information asymmetry can be characterized by the risk of trading with a privately informed investor.

The decision of the firm regarding how much earnings could be paid out as dividend and how much could be retained is the concern of dividend policy decision. The optimal dividend policy is the one that maximizes the 
company's stock price, which leads to maximization of shareholders' wealth and thereby ensures more rapid economic growth. This optimal level strikes a balance between current dividends and future growth thereby maximizing the price of the firm's stock. In practice every firm follows some kind of dividend policy, which retains a portion of the net earning in such a manner that it will not constitute a threat to dividend payment. Researchers have asserted that firms use dividends as mechanism for financial signaling to the outsiders regarding the stability and growth prospects of the firm (Okpara, 2010).

The signaling hypothesis is based on the notion of asymmetric information particularly between managers and investors. Under this assumption dividend changes are valuable in that they convey information about the firm's prospects. Information signaling theory" of dividends, argues that dividends reduce asymmetric information by acting as a signaling mechanism \{See Bhattacharya (1979), Miller and Rock (1985), John and Williams (1985), John and Lang (1991)\}. If the managers of a firm know more about the firm's future prospects than outside investors, then changes in dividends, or the fact that dividends do not change, may signal some of that information to outside investors. Dividend increases allow firms with improved prospects to signal the good news to investors in a credible manner. Dividend decreases, which are necessitated by poor performance, force firms to signal bad news. And no changes in dividends signal that a firm's prospects have not materially changed. Thus, dividends signal information and changes in dividend policy in particular are important in reducing information asymmetry (Khang and King, 2002).

Lintner (1956) observed that managers are more wiling to raise rather than reduce dividend levels, and this has been widely interpreted as indicating that dividend decreases are associated with negative signals while dividend increases signal positive news. The objective of this study is to determine the impact of information asymmetry on dividend policy and the causal effect existing between the two variables.

\section{Literature Review}

Miller and Rock (1985) emphasized the information-content effect of dividends in their work. They developed a model in which dividend announcement effects emerged from the asymmetry of information between owners and managers. The dividend announcement provided share holders and the market place the missing piece of information about current earnings upon which earlier estimation of the firm's future (expected) earnings is based. The explanation regarding the signaling theory given by Bhattacharya (1979) and Williams (1985) asserted that dividends allay information asymmetry between managers and shareholders by delivering inside information of firms' future prospects. The implication of Williams assertions just like that of John and Lang (1991) suggested that managers know more about the real value of the firm than investors and as such direct the information in the market by profit dividing.

Jensen, Soberg and Zorn (1992) linked the interaction between financial policies (dividend payout and leverage) and insiders' ownership to informational asymmetries between insiders and external investors. They found that corporate financial decisions and insider ownership are interdependent. Wang, Erickson and Gau (1993) evaluated the dividend policies and dividend announcement effects using a sample of 102 real estate investment trusts in the United States. Applying the agency cost hypothesis to predict the dividend policies and the determinants of the dividend payouts, they found significant evidence to support the agency cost hypothesis. D' Souza (1999) found negative relationship between agency cost and market risk with dividends payout. While some dividend decisions are backward looking in that they simply reflect current and past earnings, some other decisions are forward looking because they reveal mangers' superior information about future earnings. According to Fama and French (2001), the firms should follow a life cycle and reflect management's assessment of the importance of market imperfection and factors including taxes to equity holders, agency cost, asymmetric information, floating cost and transaction costs.

In the words of Khang and King (2002), the payment of dividends reduces free cash flow, forcing firms to enter the capital markets more frequently and divulge information as they attempt to get financing for their operations and investments. This subjects them to the scrutiny of investment bankers, analysts, and potential new investors more often and serves to reduce the agency problem as well as reduce the level of information asymmetry between managers and investors. Thus, higher dividends should be associated with reduced information asymmetry, all else being equal.

Li \& Zhao (2007) figured out the asymmetric information effects on dividend policy. They studied some examples from IBES files during 1983 to 2003. The samples included observations of 22413 firms. The result showed a positive correlation between predicted deviation and asymmetric information and also proved that with permanence of other factors, the firms with more asymmetric information have lower probability for dividend payment. Likewise, their findings show that there is a weak and negative relation between recalled stock and amount of asymmetric information. In their examination of how informational asymmetries affect firms' dividend policies, they found that 
firms that are more subject to information asymmetry are less likely to pay, initiate, or increase dividends, such firms therefore disburse smaller amounts. Their results do not support the signaling theory of dividends as they concluded that there is a negative relation between asymmetric information and measures of dividend policy.

\section{Methodology}

The data used were sourced from the published data of the Nigerian Securities and Exchange Commission; Annual Reports and Accounts of the Nigerian Stock Exchange, various issues; the Nigerian Stock Exchange Fact Books; and the Statistical Bulletin of the Central Bank, various issues. All data sourced whether major or controlled variables are market data. This section is divided into model specification and method of data analysis.

\subsection{Specification of the Model}

In this analysis, dividend yield (DY), which is given by dividend per share divided by the stock price, is used as dependent variable. Dividend yield measures the current return from dividend income of the stock and it is used here as a proxy for dividend policy.

To proxy information asymmetry (infasy), predicted return deviation to real return is used as a quantity criterion for the measurement. This is the difference between the last period return (predicted) and the present period return (real return) divided by the real return. This variable is the major explanatory variable. Other control variables are defined as follows.

- Liquidity (LIQ), measured by value-traded ratio, which is given by total value of share traded, divided by Gross Domestic Product. It refers to the ease with which an asset can be turned to cash.

- Market size (Size). Here the researcher uses the number of listed companies in the Nigeria stock exchange each year to measure the size of the market. This is an important indicator of stock market development.

- Turnover ratio (TOR.) is calculated as the ratio of shares traded in the Nigerian stock exchange and the total market capitalization. It is used as an index of comparison for market liquidity rating and level of transaction costs. It is also the measure of the value of securities transaction relative to the size of the securities market.

- Current ratio (CR). This measures the ability of the listed companies to make payments for their current liabilities. It is given as current assets divided by current liabilities.

- Earnings or profit after tax (EAT). This is the total profits realized after all taxes and interests have been deducted.

- $\quad$ Last years dividend is the totality of dividends realized in the previous year (LYDIV).

Having explained the market variables, the model to be estimated and evaluated are functionally stated as follows:

Dividend Policy $=\mathrm{f}($ Asyinf, LIQ, Size, TOR, CR, EAT, LYDIV $)$

Where

$\mathrm{f}_{\text {Asyinf }}>$ or $<0, \quad \mathrm{f}_{\text {LIQ }}>0, \mathrm{f}_{\text {Size }}<0, \mathrm{f}_{\mathrm{TOR}}>0, \mathrm{f}_{\mathrm{CR}}>0, \mathrm{f}_{\mathrm{EAT}}>0, \mathrm{f}_{\text {LYDIV }}>0$

The a priori expectation of the information asymmetry could be positive or negative depending on the nature of the reaction. Liquidity, turnover ratio, current ratio, earnings after tax and last years dividend are by a priori meant to exert positive influence on information asymmetry while size of the market is expected to exert a negative impact on dividend policy.

\subsection{Method of Data Analysis}

The formulated model will be tested for stationarity using the Augmented Dickey Fuller Unit root test to be sure that one is not analyzing inconsistent and spurious relationship. A series that exhibits a stochastic trend, or even simply wanders around at random will not be stationary and cannot be forecasted far in the future. A stationary series will constantly return to a given value and no matter the starting point, in the long-run, it is expected to attain that value (Hall, 1994). To illustrate the use of Dickey Fuller test, one can state the autoregressive AR(1) process. Thus,

$$
\mathrm{Y}_{\mathrm{t}}=\mu+\rho \mathrm{Y}_{\mathrm{t}-1}+\varepsilon_{\mathrm{t}}
$$

Where $\mu$ and $\rho$ are parameters and $\varepsilon_{t}$ is the white noise assumption. $Y$ is a stationary series if $-1<\rho<1$. Nevertheless, the above description is valid only if the series is an $\operatorname{AR}(1)$ process. If $\rho=1, Y$ is a non-stationary series (a random walk with drift). The hypothesis of a stationary series can therefore be evaluated by testing whether the absolute value of $\rho$ is strictly less than one (Dickey and Fuller, 1981). Thus, $\mathrm{H}_{0}: \rho=0$ and $\mathrm{H}_{1}: \rho<1$. If the series is correlated at higher order lags, the assumption of white noise disturbance is violated and the ADF test makes a parametric correction for higher order by assuming that the $\mathrm{Y}$ series follows an $\operatorname{AR}(\rho)$ process. The test 
methodology is then adjusted by adding lagged difference terms of the dependent variable $\mathrm{Y}$ to the right hand side of the regression. Thus,

$$
\Delta \mathrm{Y}_{\mathrm{t}}=\mu+\gamma \mathrm{Y}_{\mathrm{t}-1}+\delta_{1} \Delta \mathrm{Y}_{\mathrm{t}-1}+\delta_{2} \Delta \mathrm{Y}_{\mathrm{t}-2}+\ldots \ldots . .+\delta_{\mathrm{p}-1} \Delta \mathrm{Y}_{\mathrm{t}-\mathrm{p}+1}+\varepsilon_{\mathrm{t}}
$$

The hypothesis for the augmented specification is tested thus;

$\mathrm{H}_{0}: \gamma=0$ and $\mathrm{H}_{1}: \gamma<0$.

A non-stationary series could be made stationary by differencing once or twice. This is called an integrated series. It could be integrated of order 1 which is often denoted as I(1) or order 2 represented by I(2). The stationary linear combination of the variables under consideration is called cointegration equation (Engle and Granger, 1991).

That variables are cointegrated, implies that they share a long-run relationship and will move closely together over time; meaning that the difference between such variables are stable over time and there is some degree of convergence in the long-run.

To test for cointegration, Johansen's (1991) method is to test the restrictions imposed by cointegration on the unrestricted vector autoregresions (VAR) involving the series. If the VAR is of order P, the starting equation can be stated as

$$
\mathrm{Y}_{\mathrm{t}}=\mathrm{A}_{1} \mathrm{Y}_{\mathrm{t}-1}+\mathrm{A}_{2} \mathrm{Y}_{\mathrm{t}-2}+\ldots \ldots \ldots \ldots+\mathrm{A}_{\mathrm{p}} \mathrm{Y}_{\mathrm{t}-\mathrm{p}}+\mathrm{BX}_{\mathrm{t}}+\varepsilon_{\mathrm{t}}
$$

Where $Y_{t}$ is a $k$ - vector of non-stationary $I(1)$ variables, $X_{t}$ is a d vector of deterministic variables and $\varepsilon_{t}$ is a vector of innovations. The VAR can be re-written as:

$$
\Delta \mathrm{Y}_{\mathrm{t}}=\prod_{\mathrm{t}-1}+\sum_{\mathrm{i}-1}^{\mathrm{P}-1} \Gamma_{\mathrm{i}} \Delta \mathrm{Y}_{\mathrm{t}-\mathrm{i}}+\mathrm{BX}_{\mathrm{t}}+\varepsilon_{\mathrm{t}}
$$

Where

$$
\Pi=\sum_{i=1}^{\mathrm{P}} \mathrm{A}_{\mathrm{i}}-\mathrm{I}, \quad \Gamma_{\mathrm{i}}=-\sum_{\mathrm{i}=\mathrm{i}+1}^{\mathrm{P}} \mathrm{A}_{\mathrm{j}}
$$

Granger's (1969) representation theorem asserts that if the coefficient matrix $I I$ has reduced rank $r<k$, then there exist $k \mathrm{x} r$ matrices $\alpha$ and $\beta$ each with rank $r$ such that $I I=\alpha \beta$ and $\beta \mathrm{y}_{\mathrm{t}}$ is stationary. $\mathrm{r}$ is the number of cointegrating relations (the cointegrating rank) and each column of $\beta$ is the cointegrating vector. The elements of $\alpha$ are known as the adjustment parameters in the vector error correction model. Johansen's method is to estimate the $I I$ matrix in an unrestricted form, then test whether we can reject the restrictions implied by the reduced rank of II (see Eviews study pack).

The presence of cointegration forms the basis for error correction model specification. The dynamics of dividend policy is then specified in an error correction model $\left(\mathrm{ECM}_{\mathrm{t}}\right)$, incorporating the one period lagged residual from the static regression. The error correction model is designed to capture the short-run deviations that might have occurred in estimating the long-run co-integrating equation (Engle and Granger,1987). Thus, the dividend policy model will be re-specified as follows to include an error correction term (ECM)

DividendPolicy $=\lambda_{0}+\lambda_{1}$ Asyinf $+\lambda_{2} \mathrm{LIQ}+\lambda_{3} \mathrm{Size}+\lambda_{4} \mathrm{TOR}+\lambda_{5} \mathrm{CR}+\lambda_{6} \mathrm{EAT}+\lambda_{7} \mathrm{LYDIV}+\mathrm{ECT}_{\mathrm{t}-1}+\mathrm{u}_{\mathrm{t}}$

The yearly data for the above mentioned market variables are presented in table I in the appendix.

The researcher also employed the Granger causality test, as correlation does not necessarily imply causation in any meaningful sense of the word. The Granger (1969) approach to the question of whether X causes Y is to see how much of the current $\mathrm{Y}$ can be explained by past values of $\mathrm{Y}$ and then to see whether adding lagged values of $\mathrm{X}$ can improve the explanation. $\mathrm{Y}$ is said to be granger-caused by $\mathrm{X}$ if $\mathrm{X}$ helps in the prediction of $\mathrm{Y}$, or equivalently if the coefficients of the lagged X's are statistically significant. In this study, dividend policy signifies $Y$ while information asymmetry represents $\mathrm{X}$. The Granger test is predicated on the following regression analysis:

$\mathrm{Y}_{\mathrm{t}}=\beta_{0}+\sum \beta_{1 \mathrm{i}} \mathrm{Y}_{\mathrm{t}-\mathrm{i}}+\sum \beta_{2 \mathrm{i}} \mathrm{X}_{\mathrm{t}-\mathrm{i}}+\mu_{\mathrm{t}}$

$\mathrm{X}_{\mathrm{t}}=\alpha_{0}+\sum \alpha_{1 \mathrm{i}} \mathrm{X}_{\mathrm{t}-\mathrm{i}}+\sum \alpha_{2 \mathrm{i}} \mathrm{Y}_{\mathrm{t}-\mathrm{i}}+\mathrm{v}_{\mathrm{t}}$

Where $Y_{t}$ and $X_{t}$ are variables to be tested - dividend policy and information asymmetry, and $\mu$ and $v_{t}$ are the idiosyncratic terms that capture all variations in $Y_{t}$ and $X_{t}$ not in the lagged values. 


\section{Empirical Results and Discussions}

The results of the Augumented Dickey-Fuller test are presented in table 2 in the appendix. These results show that all the variables are integrated of order two, 1(2) at 5 percent level of significance with lag 1. In other words, they are found to be stationary after differencing twice. Thus, the model follows integrating process.

The next step after establishing the stationarity (or order of integration) of the variables is to determine whether there exist any cointegrating vector supporting the existence of long-run relationship between the dependent variables and the explanatory variables. To do this, the Johansen test is used. The result of the test is presented in table 3 in the appendix.

The test indicates the presence of 3 cointegrating equations at 5 percent level of significance thereby confirming the existence of long-run equilibrium relationship between the variables. Thus, 3 linear combinations of the variables are stationary.

With this result, one proceeds to specify the short run dynamic equation. The short-run dynamics is specified as an error correction model (ECM) incorporating the one period lagged residual from the static regression. The autoregressive distributed lag technique is used with a maximum lag of 1 to obtain an over-parameterized equation. Finally, a parsimonious result is obtained in table 4 and it is presented in the appendix.

The results in table 4 show that in the long-run, dividend policy is positively and significantly related to information asymmetry lagged one year. In other words higher asymmetric information leads to higher dividend policy. This result is consistent with the findings of Battacharya (1979) Miller and Rock (1985), William and John (1985), John and Lang (1991), Khang and King (2002) who found a meaningful and positive relationship between dividend policy and asymmetric information. But contrary to the results of Li and Zhao (2008) Lee and Jaho (2007) and that of Valipor, Rostami and Salehi (2009). The Granger causality tests (at lag 2) show a significant causality between dividend policy and information asymmetry $(\mathrm{F}=6.51498$ with probability of 0.01097$)$. Thus, dividend policy Granger causes information asymmetry and not the other way round. In other words, dividend policy predicts information asymmetry with no reverse or feedback effects.

The study also controls for other market characteristics such as earning after tax (EAT), liquidity, last years dividend, size and turn over ratio; and found that liquidity exerts a negative and significant influence on dividend policy. While dividend policy is a positive and significant function of the rest of the control variables.

The parsimonious model exhibited a goodness of fit showing that the explanatory variables explain about 61.8 percent of the systematic variation in dividend policy. Also the overall regression $(\mathrm{F}=8.09)$ is significant. The ECM is negative and significant indicating that the model is able to correct any deviation from the long-run equilibrium relationship between the dependent and the explanatory variables. There is therefore empirical evidence that there exist a long-run relationship between dividend policy and information asymmetry under some controlling variables.

\section{Conclusions}

Information asymmetry occurs in the stock market when some investors' possess private information about the firm's value which others are not privileged to have within the period. The study investigated the long run effect of this dichotomy of information on dividend policy and found that dividend policy is a positive and significant function of information asymmetry. This finding is consistent with dividend signaling models. The policy implication is that insiders have privileged information of the real value of the firm and usurp this information for profit dividing.

In addition, liquidity exerts a negative and significant influence on dividend policy while the rest of the variables considered exert a positive and significant influence on the policy.

\section{References}

Admati, A.R. \& P. Pfleiderer P. (1999). Selling and Trading on Information in Financial Markets, American Economic Review, 78, 2, 96 - 103196.

Bhattacharya, S. (1979). Imperfect Information, Dividend Policy, and 'The Bird in the Hand' Fallacy, Bell Journal of Economics, Vol. 10, $259-270$.

Bick, A. (1987). On the consistency of the Black-Scholes model with a general equilibrium framework. Journal of financial and quantitative analysis 22, 259-275.

Brown, S and Stephen A. Hillegeist. (2003). Disclosure Quality and Information Asymmetry", working papers, University of Utah 
Diamond, D.W. \& Verrecchia, R.E. (1991). Disclosure, Liquidity, and the Cost of Capital, Journal of Finance, vol. 46, No.4, $1325-1360$.

Dickey DA and Fuller W (1981). Likelihood Ratio Statistics for Autoregressive Time Series with a Unit Root. Econometrica, 49, 1057-1072.

Dsuza J (1999). Agency Cost, Market Risk, Investment Opportunities and Dividend Policy. Journal of Manager Financials, Vol. 25.

Easley, D. \& O’Hara, M. (1992). Time and the Process of Security Price Adjustment, Journal of Finance, vol. 47, No.2, p.29.

Engle, R.F. \& Granger, C.W.J. (1987). Co-integration and Error Correction: Representation, Estimation and Testing. Econometrica 55: 251-276.

Engle, R.F. \& Granger, C.W.J. (1991). Long-run Economic Relationships, Reading in Cointegration (eds.) Advanced Texts in Econometrics, Oxford University Press, Oxford. Eview Software Study Pack.

Fama, E.F. \& French, K.R. (2001). Disappearing Dividends: Changing firm characteristics or lower propensity of pay? Journal of Financial Economics, vol.60, No. 1, pp 3-43.

Finnerty, Joseph. (1979). Insiders and marker efficiency, Journal of Finance, vol.31, pp. 1141 -1148.

Franke, G.,R.C. Stapleton, and M.G. Subrahmnaya. (1999). When are options overpriced? The black-scholes model and alternative characterization of the pricing kernel, European finance review 3, $72-102$.

Glosten, L. \& Milgrom, P. (1985). Bid, Ask, and Transaction prices in a specialist market with heterogeneously informed agents, journal of financial economic vol.14, pp. $71-100$.

Granger, C.W.J. (1969). Investigating Causal Relations by Econometric Models and Cross- Spectral Models. Econometrica :424-438.

Hall S G (1994). Applied Economic Forecasting Techniques. Harvester Wheatsheaf, New York.

Hasbrouck, J. (1991). Measuring the information content of stock trades, journal of finance, vol.46, No.1, p.29.

Jaffe, Jeffrey. (1974). Special information and insider trading, journal of business, vol.47, pp. 410-428.

Jeng, Leslie, Andrew Metrick, \& Joseph Zeckhauser. (1999). The Profits to Insider Trading: a Performance-Evaluation Perspective, Working Paper 6913, National Bureau of Research.

Jensen, G.R. Donald, P.S. and Thomas Zorn, (1992), 'Simultaneous Determination of insider Ownership, Debt and Dividend Policies'. Journal of Financial and Quantitative Analysis, vol.27, June 1992, pp. 247 - 263.

Johansen, S. (1991).Estimation and Hypothesis Testing of Cointegration Vectors in Gaussian Vector Autoregressive Models. Econometrica 59:1551-1580.

John, K. \& Williams, J. (1985). Dividends, Dilution and Taxes: A Signaling Equilibrium, Journal of Finance, vol.40, pp. $1053-1070$.

John, Kose, \& Larry Lang. (1991). Insider Trading Around Dividend Announcements: Theory and Evidence, Journal of Finance, Vol. 46, pp. 1361 - 1389.

Khang, Kenneth \& Tao-Hsien Dolly King. (2002). Is Dividend Policy Relate to Information Asymmetry? Evidence from Returns to Insider Trades, Financial Management, Vol. 35, pp. 71-94.

Kim, O. \& Verrecchia, R.E. (2001). The Relation among Disclosure, Returns, and Trading Volume Information, Accounting Review, Vol.76. No.4, pp. 633 - 654.

Kyle, A. (1985). Continuous Auctions and Insider Trading, Econometrica, Vol.53, pp. 1315 - 1335.

Lakonishok, Josef \& Inmoo Lee, (2001). Are Insider Trades Informative? Review of Financial Studies, Vol.14, pp. $79-111$.

Lease, R.C., John, K., Kalay, A., Loewenstein, U. and Sarig, O.D. (2000). 'Dividend Policy: Its Impact on Firm Value', Harvard Business School Press, Boston, MA.

Li, Kai \& Xinlei Zhao, (2007). Asymmetric Information and Dividend Policy, Journal of Financial Management, Forthcoming, Available at:http://ssrn.com.

Lintner, J. (1956). 'Distribution of Incomes of Corporations among Dividends, Retained Earnings, and Review 71, $467-492$.

Luders, E., and B. Peisl. (2001). How do investors' expectations drive asset prices? Financial review 36, 75 - 98. 
McNichols, M. \& Trueman, B. (1994). Public Disclosure, Private Information Collection, and Short-Term Trading, Journal of Accounting and Economics, Vol.17, No.1,2, pp. 69-94.

Miller M and Rock K. (1985). Dividend Policy Under Asymmetric Information. Journal of Finance 40:1031-1051.

Nwezeaku NC and Okpara GC. (2010). Stock Market Volatility and Information

Asymmetry: Lessons from Nigeria. Interdisciplinary Journal of Contemporary Research Vol.2 No.1.pp.67-79.

Okpara GC (2010) A Diagonosis of the Determinants of Dividend Pay-Out Policy in Nigeria:A Factor Analytical Approach. American Journal of Scientific Research Issue 8.pp57-67

Pandy IM (2008) Financial Management, Nineth Edition vikas Publishing House PVT Ltd, New Delhi.

Seyhum N (1986) Insiders' Profits, Cost of Trading and Market Efficiency. Journal of Financial Economics, Vol.47 pp.410-428.

Valipor H, Rostami V and Salehi M (2009) Asymmetric Information and Dividend Policy in Emerging Markets: Empirical Evidences from Iran.International Journal of Economics and Finance, Vol.1 No.1.

Wang K., Erickson, J and Gau, G.W. (1993). Divided Policies and Divided Announcement Effects for Real Estate Investment Trusts, Journal of the American Real Estate and Urban Economics Association, vol.21, No.2 pp. 185 201.

\section{Appendix}

Table 1. Nigerian Stock Market Indicators

\begin{tabular}{|l|l|l|l|l|l|l|l|l|l|l|}
\hline Year & Liquidity & Size & TOR & DY & CR & EAT & DPR & Share Price & Infasy & DIV \\
\hline 1984 & 0.04 & 93 & 0.5 & 10.4 & 75.50 & 536.4 & 0.50 & 105.5 & NA & 266.7 \\
\hline 1985 & 0.05 & 96 & 0.5 & 10.6 & 79.60 & 775.3 & 0.43 & 128.4 & NA & 335.0 \\
\hline 1986 & 0.07 & 99 & 0.6 & 9.9 & 81.50 & 837.5 & 0.42 & 163.8 & 19.3 & 351.4 \\
\hline 1987 & 0.03 & 100 & 0.7 & 11.2 & 82.40 & 914.9 & 0.51 & 190.6 & -58.8 & 463.1 \\
\hline 1988 & 0.02 & 102 & 0.4 & 10.7 & 79.10 & 1076.4 & 0.52 & 233.6 & 24.3 & 562.5 \\
\hline 1989 & 0.03 & 111 & 0.3 & 11.7 & 81.20 & 1784.9 & 0.49 & 325.3 & 39.0 & 872.7 \\
\hline 1990 & 0.01 & 131 & 0.7 & 12.0 & 87.70 & 1996.9 & 0.54 & 513.8 & 27.6 & 1081.8 \\
\hline 1991 & 0.01 & 142 & 0.5 & 10.4 & 88.50 & 2209.0 & 0.58 & 784.1 & -8.0 & 1290.8 \\
\hline 1992 & 0.01 & 153 & 0.9 & 7.0 & 106.80 & 4586.6 & 0.37 & 1107.6 & -22.6 & 1701.8 \\
\hline 1993 & 0.01 & 134 & 0.7 & 6.5 & 95.70 & 9130.8 & 0.36 & 1548.8 & 0.30 & 3247.1 \\
\hline 1994 & 0.01 & 177 & 0.7 & 8.4 & 125.20 & 18842.3 & 0.45 & 2205 & 5.10 & 8437.7 \\
\hline 1995 & 0.01 & 181 & 1.0 & 7.9 & 112.50 & 23027.0 & 0.42 & 5092.2 & 57.8 & 9726.1 \\
\hline 1996 & 0.01 & 185 & 2.5 & 9.6 & 111.70 & 25200.9 & 0.39 & 6992.1 & -1.6 & 9857.4 \\
\hline 1997 & 0.04 & 182 & 3.9 & 8.7 & 123.60 & 25289.6 & 0.41 & 6440.5 & 48.7 & 10465.4 \\
\hline 1998 & 0.05 & 186 & 5.1 & 6.6 & 117.80 & 34445.4 & 0.32 & 5672.8 & 35.4 & 10923.6 \\
\hline 1999 & 0.04 & 195 & 4.8 & 7.8 & 128.30 & 40871.1 & 0.27 & 5266.4 & -54.9 & 11185.0 \\
\hline 2000 & 0.06 & 195 & 6.0 & 7.5 & 140.60 & 52891.1 & 0.22 & 8111.0 & 1.20 & 11621.1 \\
\hline 2001 & 1.20 & 194 & 8.9 & 7.3 & 157.10 & 53574.4 & 0.54 & 10963.1 & -37.6 & 28942.4 \\
\hline 2002 & 1.10 & 195 & 7.9 & 10.8 & 135.00 & 72782.3 & 0.50 & 12137.7 & -2.50 & 36619.2 \\
\hline 2003 & 1.70 & 200 & 8.6 & 10.5 & 154.72 & 74000.0 & 0.50 & 19942.8 & 82.0 & 36818.9 \\
\hline 2004 & 2.00 & 207 & 11.6 & 11.4 & 161.04 & 85500.0 & 0.49 & 23844.5 & -1.80 & 42112.1 \\
\hline 2005 & 1.80 & 214 & 10.1 & 12.3 & 167.36 & 85880.0 & 0.55 & 24085.8 & -16.9 & 47405.3 \\
\hline 2006 & 2.60 & 202 & 11.1 & 13.1 & 173.68 & NA & NA & 33189.3 & 97.0 & \\
\hline
\end{tabular}

Sources: Nigerian Stock Exchange Annual Reports and Accounts, Various Issues;

Securities and Exchange commission Annual Report and Accounts;

Central Bank of Nigeria Statistical Bulletin 2006 and Personal computation.

NA implies not available. 
Table 2. ADF Unit Root Test Results.

\begin{tabular}{|l|l|l|l|}
\hline Variable & ADF Test Statistics & Max Lag & Order of integration \\
\hline$D($ DPR $)$ & -5.404180 & 1 & $1(2)$ \\
\hline$D(D Y)$ & -5.353102 & 1 & $1(2)$ \\
\hline$D($ Infasy) & -6.330203 & 1 & $1(2)$ \\
\hline$D($ Liquidity) & -5.629530 & 1 & $1(2)$ \\
\hline$D($ Size $)$ & -4.872455 & 1 & $1(2)$ \\
\hline$D($ TOR $)$ & -10.44917 & 1 & $1(2)$ \\
\hline$D($ CR $)$ & -6.810585 & 1 & $1(2)$ \\
\hline$D($ EAT $)$ & -3.523982 & 1 & $1(2)$ \\
\hline$D($ LYDIV $)$ & -5.467297 & 1 & $1(2)$ \\
\hline
\end{tabular}

Critical values $1 \%=-3.8572,5 \%=-3.0400,10 \%=-2.6608$

Table 3. Johansen Cointegration Test

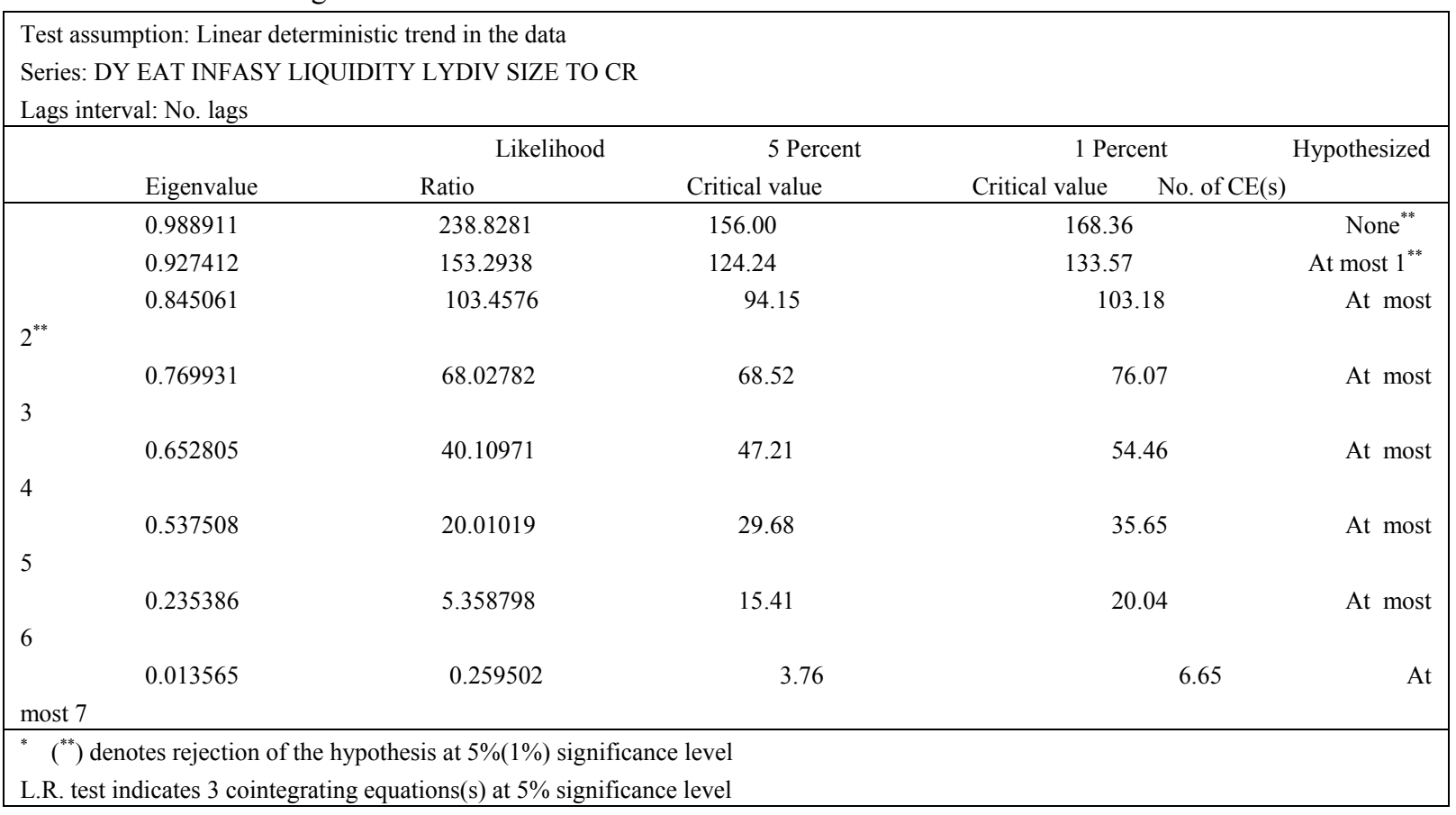


Table 4. Parsimonious Regression Results

\begin{tabular}{|c|c|c|c|}
\hline \multicolumn{4}{|l|}{ Dependent variables D(DY) } \\
\hline Variable & Coefficient & Std.Error & t-statistic \\
\hline DY-1 & 0.820375 & 0.43795 & 1.87320 \\
\hline Liquidity-1 & -14553.61 & 5865.77 & -2.48111 \\
\hline LDIV-1 & 0.0002952 & $3.4 \mathrm{E}-05$ & -8.59335 \\
\hline Size-1 & 0.052266 & 0.00378 & 13.8303 \\
\hline TOR-1 & 0.440769 & 0.06871 & 6.41526 \\
\hline EAT-1 & 0.000195 & $6.0 \mathrm{E}-05$ & 3.26399 \\
\hline INFASY-1 & 0.024809 & 0.00612 & 4.05285 \\
\hline ECT-1 & -1.278387 & 0.07483 & -17.0837 \\
\hline R-square & 0.618025 & & \\
\hline Adj. R-square & 0.541630 & & \\
\hline Sum sq. resides & 17.03490 & & \\
\hline S.E. equation & 1.065673 & & \\
\hline F-statistic & 8.089848 & & \\
\hline Log likelihood & -25.92267 & & \\
\hline Akaike AIC & 3.149755 & & \\
\hline Schwarz SC & 3.348584 & & \\
\hline Mean dependent & 0.126316 & & \\
\hline S.D. dependent & 1.574040 & & \\
\hline Determinant Residual Covariance & $9.19 \mathrm{E}+13$ & & \\
\hline Log Likelihood & & -521.1167 & \\
\hline Akaike Information Criteria & 60.74913 & & \\
\hline Schwartz Criteria & & 63.53274 & \\
\hline
\end{tabular}

